\title{
Tıbbi müdahalelerin hukuka uygunluk şartları
}

\author{
The compliance of the medical interventions with law
}

\author{
İsmail Atak
}

Avukat

\begin{abstract}
Bireyin maddi ve manevi dokunulmazlığı ile sağlık ve vücut bütünlüğüne yönelik müdahalelerin hukuka aykırılığı ve hukuk düzenlerinde yaptırıma tabi tutulmasına ilişkin yükümlülükler evrensel insan hakları kataloğunun ayrılmaz bir parçasını oluşturmaktadır. Vücut bütünlüğüne yapılan müdahalelerin yaptırım gerektirmeyecek ayrık hallerden birini de tıbbi müdahaleler oluşturmaktadır. Tıbbi müdahalenin hukuksal meşruluk taşıyabilmesi için gerekli hukuka uygunluk koşullarının uluslararası sözleşmeler, iç mevzuat ve hukuki uygulama düzleminde incelenmesi bu çalışmanın amacını oluşturmaktadır. Amaç kapsamında tıbbi müdahale ve hukuka uygunluk kavramları ile konumuz özelinde tıbbi müdahaleyi icra etme yetkisine sahip olanların bu faaliyetleri sürecinde uymaları gereken asgari şartlar olan; tıbbi müdahaleye yetkili olmak, aydınlatma yükümlülüğü, hastanın rızası kavramları hukuka uygunluk perspektifinde irdelenmektedir.
\end{abstract}

Anahtar sözcükler: tıbbi müdahale; hukuka uygunluk; hasta hakları; aydınlatılmış onam; hasta rızası

\begin{abstract}
All kinds of violations against individual's material and immaterial immunity along with their physical integrity are prohibited by enforcements created in all law systems, which have inseparable bonds with universal human rights. Medical interventions are one of the exceptional circumstances of interference of individual's physical integrity without punishment. The goal of this article is; to examine the legality of a medical intervention which has to be in compliance with the international conventions, domestic legislations and legal practices. We shall analyze the terms of our specific subject (i) to be authorized to practice medical interventions (ii) obligation to inform the patient (iii) the informed consent of the patient ; which are the minimum requirements to be obeyed by the ones who have the authority to practice medical interventions and medical interventions within the aim and the notions of compliance with laws, within the perspective of compliance of the law.
\end{abstract}

Key words: medical attention; compliance with law; patient rights; obligation to inform; patience's informed consent

\section{GENEL OLARAK TIBBI MÜDAHALE KAVRAMI}

Evrensel hukuka paralel olarak hukukumuzda da insan sağlığına ve vücut bütünlüğüne yönelen her türlü müdahale, kişilik haklarının hukuka aykırı olarak ihlâli olarak kabul edilmektedir. Bu konuda normlar piramidinin en üzerinde yer alan Anayasamızın "Kişinin Dokunulmazlığı, Maddî ve Manevî Varlığı” başlıklı 17. maddesi de birinci fikrasında yer alan "Herkes, yaşama, maddî ve manevî varlığını koruma ve geliştirme hakkına sahiptir." kapsayıcı ifadesi ile vücut bütünlügüne dokunulamaması ilkesini en temel kişilik hakkı olarak koruma altına almış bulunmaktadır. ${ }^{[1]} \mathrm{Bu}$ temel hak çerçevesinde alt mevzuatta da kişinin maddi ve/ veya manevi bütünlüğüne yönelik meşru kabul edilmeyen müdahaleler, niteliklerine göre çeşitli yaptırımlara tabi tutulmuş bulunmaktadır.
Kişi dokunulmazlığına ilişkin düzenlemelerin en temel istisnası ise yine Anayasanın 17. maddesinin 2. fikrasında "Tıbbî zorunluluklar ve kanunda yazılı haller dışında, kişinin vücut bütünlüğüne dokunulamaz; rızası olmadan bilimsel ve tıbbi deneylere tâbi tutulamaz." denilmek suretiyle belirtilmiş ve insan hayatı, sağlığı ve vücut bütünlügünü korumak için gerekli koşulların yerine getirilmesi halinde tıbbi müdahalenin hukuka uygun olabileceği kabul edilmiş bulunmaktadır. ${ }^{[1]}$

Öğretide birbiri ile uyumlu, ancak ilgili olduğu alana göre kapsam farklılıkları gösteren pek çok tanım da dikkate alındığında tıbbi müdahaleyi dar anlamıyla tıp mesleğini icraya yetkili kişiler tarafindan fiziksel ya da psikolojik rahatsızlıkların teşhisi, tedavisi ve/veya önlenmesine yönelik faaliyetler olarak tanımlamak mümkün bulunmaktadır. Tıbbi Deontoloji Tüzüğü 13 .

- İletişim adresi: Av. İsmail Atak, Hafta sokak 23/5 Gaziosmanpaşa/Ankara Tel: 0532 -371 1828 e-posta: iatak@yahoo.com

- Geliș tarihi: 18 Ekim 2019 Kabul tarihi: 29 Kasım 2019 
maddesinin kapsamı itibarı ile tıbbi müdahaleyi teşhis, tedavi ve koruma gayesine yönelik faaliyet olarak belirlemiş bulunmaktadır. ${ }^{[2]}$ Anayasa Mahkemesi'nin bireysel bir başvuru ile ilgili olarak verdiği 11.11.2015 tarih ve 2013/1789 sayılı kararında da tıbbi müdahale "hastalıkların teşhisi, tedavisi veya önlenmesi amaçlarına yönelik olarak tıp mesleğini icraya yetkili kişiler tarafından gerçekleştirilen faaliyetler" olarak tanımlanmış bulunmaktadır. ${ }^{[3]}$ Ancak sürekli gelişen teknoloji ve tıp bilimi çerçevesinde birey rızasına dayalı sterilizasyon, yapay döllenme, kürtaj, nakil amaçlı doku ve organ alınması gibi tedavi amacı dışındaki faaliyetlerin de tıbbi müdahale kavramı içerisinde değerlendirilmesi gerektiği öğretide ifade edilmektedir. ${ }^{[4]}$

Biyotıp Araştırmalarına illişkin İnsan Hakları ve Biyotıp Sözleşmesine Ek Protokol madde 2/3 “ $B$ u protokolün amaçları bağlamında "müdahale" terimi, 1. Bir fiziksel müdahaleyi ve 2. Il|gili kişinin psikolojik sağ/ığı açısından risk taşıyan herhangi bir müdahaleyi içerir." ifadelerine yer verilmiştir. ${ }^{[5]}$ Hasta Hakları Yönetmeliği 4. maddesinde de tıbbi müdahale "tıp mesleğini icraya yetkili kişiler tarafindan uygulanan, sağlığı koruma, hastalıkların teşhis ve tedavisi için ilgili meslekî yükümlülükler ve standartlara uygun olarak tıbbın sınırları içinde gerçekleştirilen fizikî ve ruhî girişimi ifade eder" şeklinde tanımlanmıştır. ${ }^{[6]}$

Geniş anlamda bir tıbbi müdahale; kişilerin bedenseli fiziksel veya psikolojik bir hastalığını, noksanlığını teşhis ve tedavi etmek, bu mümkün olmadığında hastalığı hafifletmek veya acılarını dindirmek veyahut rahatsızlıktan korumak ya da nüfus planlaması amaçlarıyla tıp mesleğini icraya yasal olarak yetkili kimseler tarafından, tıp bilimince genel kabul görmüş kural ve esaslara uygun olarak gerçekleştirilen, en basit teşhis ve tedavi yöntemlerinden başlayarak en ağır cerrahi müdahalelere kadar uzanan her çeşit faaliyet olarak tanımlanabilir. ${ }^{[7,8]}$ Bir başka tanımda ise teşhis, tedavi, korunma, ilaç yazılması, tahlil (laboratuvar, röntgen vb), estetik cerrahi, psikiyatrik müdahale, adli muayene gibi örneklerden hareketle "insan üzerinde tıp biliminin uygulanması ile bağlantılı olarak yapılan her türlü müdahale tıbbi müdahale olarak" ifade edilmektedir. ${ }^{[9]}$

Tüm bu tanımlamalar ışığında tıbbi müdahaleyi; yaşanan bilimsel gelişmeler ve ihtiyaçlara bağlı olarak oluşacak kavramsal örnekleme çeşitliliğine açık tutarak, teşhis tedavi ve koruma faaliyet süreçlerinin tamamı ya da bir kısmı olarak kabul edebiliriz.

\section{TIBBi MÜDAHALENIN HUKUKA UYGUNLUĞU}

Tıbbi müdahalede bulunan kimselerin bu faaliyetleri nedeniyle hukuki, cezai, idari ya da mesleki bir sorumlulukla ve buna bağlı olarak herhangi bir yaptırımla karşılaşmamaları, eylemlerinin meşru kabul edilebilmesi için müdahalelerinin hukuka uygun olması gerekmektedir. ilgili mevzuat çerçevesinde; endikasyon ön koşuluna bağlı olarak yapılacak tıbbi müdahalenin hukuka uygunluğu için esas itibarıly gerçekleşmesi gereken koşulları şu şekilde sıralamak mümkün bulunmaktadır:

1. Tıbbi müdahaleyi icra eden kişinin somut olaydaki tıbbi müdahaleye yetkili olması

2. Hastanın aydınlatılmasına dayalı rızasının alınması

3. Tıbbi müdahalenin dikkat ve özen yükümlülüğüne uygun bir biçimde, tıp biliminin en son veri ve olanaklarına uyumlu olarak yerine getirilmesi

\section{Tıbbi müdahaleyi icra eden kişinin somut olaydaki tıbbi müdahaleye yetkili olması}

Bir tıbbi müdahalenin hukuka uygun kabul edilebilmesinin ilk koşulu tıbbi müdahalede bulunan kişinin söz konusu tıbbi müdahalede bulunmaya yetkili olması gerekmektedir. 1219 sayılı Tababet ve Şuabatı Sanatlarının Tarzı İcrasına Dair Kanunun 1. maddesinde "Türkiye Cumhuriyeti dâhilinde tababet icra ve herhangi surette olursa olsun hasta tedavi edebilmek için tıp fakültesinden diploma sahibi olmak şarttır." denmek suretiyle tıbbi müdahaleye yetkili olanların esas itibarı ile hekimler olduğu belirtilmiş bulunmaktadır. Anılan Kanunun 2946. maddelerinde diş hekimlerine ilişkin düzenlemelere yer verilmiş; kanunun 3. maddesinde acil tıp teknikerleri ve sağlık astsubaylarının hastaya müdahale edebileceği belirtilmiş; 63- 68. maddelerinde hastabakıcı hemşireler ile ilgili düzenlemeler yapılmış; Ek 13. maddede ise diğer sağılı mesleği mensupları tek tek sayılmış olmakla birlikte madde metninde yer verilen "Tabipler ve diş tabipleri dışındaki sağıı meslek mensupları hastalıklarla ilgili doğrudan teşhiste bulunarak tedavi planlayamaz ve reçete yazamaz." hükmü ile madde metninde sayılan sağlık mesleği mensuplarının ancak bir hekimin teşhis ve tedavi planlamasına bağı olarak faaliyette bulunabilecekleri ve tıbbi müdahaleye dâhil olabilecekleri açıkça belirlenmiş bulunmaktadır. ${ }^{[10]}$

Yasal düzenlemeler kapsamında hekimlerin durumunun incelenmesinde değinilmesi gereken diğer bir durumda müdahalenin gerektirebileceği uzmanlık yeterliliğidir. Tababet ve Şuabatı Sanatlarının Tarzı İcrasına Dair Kanunun 3. maddesi ilk fikrası ile (Tababet ve Şuabatı Sanatlarının Tarzı Icrasına Dair Kanun, madde 3/1 "Yukarıdaki maddelerde zikredilen tabip diplomasını ve fennî, cerrahi veya şuabatında ihtisas sahibi olduğuna dair işbu kanunun tarifleri dairesinde vesaikı lâzimeyi (gerekli belgeleri) haiz olmıyan hiç bir kimse hiç bir ameliyei cerrahiye icra edemez) cerrahi müdahaleler için uzmanlık belgesine sahip olma gerekliliği belirtilmiş; 23. maddesi ile de önemli cerrahi müdahalelerde mutlaka uzman hekimin bulunması şartı 
hüküm altına alınmış bulunmaktadır (23. madde düzenlemesine göre uzman bulunması veya çağırılması mümkün olmayan mahallerde yapılması zorunlu durumlar ile acil ve olağanüstü durumlar hükümden istisna tutulmuş bulunmaktadır). ${ }^{[10]}$

Anılan Kanuna dayanılarak çıkartılan ve 26.04.2014 tarihinde yayınlanarak yürürlüğe giren Tıpta ve Diş Hekimliğinde Uzmanlık Eğitimi Yönetmeliği'nde uzman, "sayılı kanun eki çizelgelerde yer alan dallardan birinde uzmanlık eğitimini tamamlayarak o dalda sanatını uygulama hakkı ve uzmanlık unvanını kullanma yetkisi kazanmış olanlar" şeklinde tanımlanmakta olup; yönetmeliğin "Uzmanlık Yetkisinin Kullanılması başlıklı 27. maddesinde yönetmelik hükümlerine göre uzmanlık belgesi almayanların, hiçbir yerde ve şekilde uzmanlık unvan ve yetkisini kullanamayacakları belirtilmiştir. ${ }^{[11]}$ Mevzuatımızda yer alan düzenlemeler karşısında uzmanlık eğitimi ve belgesini almamış bulunan bir hekimin, müdahalenin gerektirdiği uzmanlık alanında zorunluluk halleri dışında tıbbi müdahalede bulunamayacağı; herhangi bir alanda uzmanlık belgesine sahip hekimin ise temel tıp bilgilerine sahip olması nedeniyle pratisyen hekimlerin icra edebileceği tıbbi müdahalelerde bulunmasında hukuka aykırılık olmayacağı söylenebilecektir.

İntörn hekimler henüz diploma almadıkları için hekim sayılmayacaklarından özel hukuk bakımından sorumlulukları yardımcı şahıs sorumluluğuna göre belirlenecek olup; ceza hukuku bakımından ise, ancak ilgili hekimin gözetimi altında yapacakları tıbbi müdahalelerden sorumlu tutulmayacaklardır. ${ }^{[9]}$

\section{Hastanın aydınlatılmasına dayalı rızasının alınması}

Nispî anlamda kişiye sıkı sıkıya bağlı haklardan biri olan vücut ve ruh bütünlüğü üzerinde tasarruf anlamına gelen tıbbi müdahaleye hasta rızasının bulunması gerekli olup; bireyin rızası alınmaksızın hayatına ve vücut bütünlüğüne yapılacak her türlü müdahale hukuka aykırı olacaktır.

Dünya Tabipler Birliği Lizbon (1981), Amsterdam (1994) ve Bali (1995) Bildirgeleri hastanın yeterli bilgileri aldıktan sonra tedaviyi kabul veya reddetme hakkına sahip olduğuna vurgu yapmaktadır. Kasım/2002 tarihinde Roma'da kabul edilen Hasta Haklarına İlişkin Avrupa Statüsü kapsamında da hastanın bilgilenme ve rıza hakkı daha detaylı olarak irdelenmiştir. ${ }^{[12-15]}$

08.12.2003 tarihli Resmi Gazetede yayımlanarak yürürlüğe girmiş ve iç hukukumuzun bir parçası haline gelmiş bulunan Biyoloji ve Tıbbın Uygulanması Bakımından İnsan Hakları ve Insan Haysiyetinin Korunması Sözleşmesi (Avrupa Biyotıp Sözleşmesi)'nin "Amaç” başlıklı 1. maddesi sözleşmenin taraflarının, tüm insanların haysiyetini ve kimliğini korumak ve biyoloji ve tıbbın uygulanmasında, ayırım yapmadan herkesin, bütünlüğüne ve diğer hak ve özgürlüklerine saygı gösterilmesini güvence altına almakla yükümlü olduklarını ifade etmektedir. ${ }^{[16]}$ Sözleşmenin 5. maddesinde ise "Rıza" konusu düzenlenmiştir. Madde düzenlemesine göre; "Sağlık alanında herhangi bir müdahale, ilgili kişinin bu müdahaleye özgürce ve bilgilendirilmiş bir şekilde muvafakat etmesinden sonra yapılabilir. Bu kişiye, önceden, müdahalenin amacı ve niteliği ile sonuçları ve tehlikeleri hakkında uygun bilgiler verilecektir. ilgili kişi muvafakatini her zaman serbestçe geri alabilecektir." Madde düzenlemesinden de anlaşılabileceği üzere tıbbi müdahalenin yapılabilmesinin ön koşulu ilgilinin kendisine uygulanacak ve tıbbi gereklilik arz eden müdahalenin amaç/nitelik ve sonuçları ile tehlikeleri hakkında uygun şekilde bilgilendirilmesi ve bunun sonrasında kendisinin hiçbir etki ve baskı altında olmaksızın özgür iradesi ile bu müdahaleye izin vermesidir. Bu fasılda belirtmek gerekir ki; tıbbi müdahalenin hukuka uygunluk koşulu olan rızanın ön şartı da endikasyonun varlığıdır. Bu husus Hasta Hakları Yönetmeliği "Tıbbi Gereklilikler Dışında Müdahale Yasağı” başlıklı 12. maddesinde "Teşhis, tedavi veya korunma maksadı olmaksızın, ölüme veya hayati tehlikeye yol açabilecek veya vücut bütünlüğünü ihlal edebilecek veya akli veya bedeni mukavemeti azaltabilecek hiçbir şey yapılamaz ve talep de edilemez" denilmek suretiyle açıkça belirtilmiş bulunmaktadır. ${ }^{[6]}$ Dolayısıyla hekim ancak endikasyonun varlığı halinde müdahale edebilir; yani endikasyon hukuka uygunluk nedeni, rıza hukuka uygunluk sınırıdır. ${ }^{[9]}$

Tababet ve Şuabatı Sanatlarının Tarzı İcrasına Dair Kanun'un 70. maddesi ile de tabipler, diş tabipleri ve dişçilerin yapacakları her nevi ameliye için hastanın, hasta küçük veya tahtı hacirde (kısıt altında) ise veli veya vasisinin muvafakatinin alınmasını, büyük cerrahi müdahaleler için bu muvafakatin yazılı olması gerektiği hususunu zorunlu kılmış bulunmaktadır. ${ }^{[10]}$

Hasta Hakları Yönetmeliği 24. ve 26. maddelerinde de genel mevzuata paralel biçimde tıbbi müdahale için hastanın rızasının gerekliliği ve bunun geçerlilik koşulları tadat edilmiş bulunmaktadır. ${ }^{[6]}$

Hasta rızasının hukuki geçerlilik taşıyabilmesi için öncelikle onun ayırım gücüne sahip olması, yani uygulanacak olan tıbbi müdahalenin önem, sebep ve sonuçlarını, kapsam ve etkilerini anlayabilme yeteneğine sahip olması, ayrıca küçük ya da kısıtlı olmaması, bir başka deyişle Medeni Kanun anlamında tam ehliyetli olması gerekmektedir. Tam ehliyetli kişiler, yani 18 yaşından büyük ve ayırım gücüne sahip kişiler fiil ehliyetine sahip olduklarından rıza gösterme yetenekleri konusunda bir problemle karşılaşılmamaktadır. 
Rıza ehliyetine sahip olma konusunda küçüklerin ve kısıtıların durumlarına ilişkin olarak da mevzuatımızda çeşitli hükümler yer almaktadır. 1219 Sayılı Tababet ve Şuabatı Sanatlarının Tarzı İcrasına Dair Kanun'un 70. maddesi düzenlemesiyle hastanın küçük veya kısıtlı olması halinde veli veya vasisinin muvafakatinin alınmasını zorunlu kılmış olduğu gibi, Hasta Hakları Yönetmeliği 24. maddesi birinci fikrası ile de kanuna paralel düzenleme yapılmış bulunmaktadır. (Hasta Hakları Yönetmeliği m. 24/1 "Tıbbi müdahalelerde hastanın rızası gerekir. Hasta küçük veya mahcur (kısıtlı) ise velisinden veya vasisinden izin alınır. Hastanın, velisinin veya vasisinin olmadığı veya hazır bulunamadığı veya hastanın ifade gücünün olmadığı hallerde, bu şart aranmaz." ${ }^{[6,10]}$ Yasal düzenlemeler kapsamında ayırım gücü olmayan, tam ehliyetsiz küçüklerin ve kısıtılıarın durumları düşünsel herhangi bir tartışma içermemekte, bu durumda olanlara yönelik tıbbi müdahalede bulunabilmek için veli ya da vasilerinin rızasına başvurulmasının zorunlu olduğu açıktır. Ayırım gücüne sahip küçüklere tıbbi müdahale için de yasal temsilcinin rızası şart olmakla birlikte; Hasta Hakları Yönetmeliğinin 24. maddesinde yer alan “ Kanuni temsilcinin rızasının yeterli olduğu hallerde dahi, anlatılanları anlayabilecekleri ölçüde, küçük veya kısıtı olan hastanın dinlenmesi suretiyle mümkün olduğu kadar bilgilendirme sürecine ve tedavisi ile ilgili alınacak kararlara katılımı sağlanır." düzenlemesiyle küçüklerin de rızaya katılımlarının sağlanması amaçlanmıştır. Anılan maddede de belirtildiği üzere; küçüğün katılımı sadece gereklilik düzeyinde olup; hukuken geçerli olan ve hekimin almakla yükümlü olduğu rıza, yasal temsilcinin rızasıdır. ${ }^{[6]}$

Avrupa Biyotıp Sözleşmesi'nin "Muvafakat verme yeteneği bulunmayan kişilerin korunması" iç başlıklı 6. maddesinde de Kanuna göre bir müdahaleye muvafakatini verme yeteneği bulunmayan bir küçüğe ya da akıl hastalığı, bir hastalık veya benzer nedenlerden dolayı, müdahaleye muvafakat etme yeteneği bulunmayan bir yetişkine sadece temsilcisinin veya kanun tarafindan belirlenen makam, kişi veya kuruluşun izni ile müdahalede bulunabileceği düzenlenmiş; ilgili kişinin mümkün olduğu ölçüde izin verme sürecine katılması gerektiği belirtilmiş bulunmaktadır. ${ }^{[16]}$

Hukukumuzda rızanın aranmadığı ayrık durumlar da mevcuttur. Kamu düzeninin gerektirdiği haller (Umumi Hıfzıssıhha Kanunu, madde 57) dışında; hastanın, velisinin veya vasisinin olmadığı veya hazır bulunamadığı veya hastanın ifade gücünün olmadığı; hayati tehlikesinin bulunduğu ve bilincinin kapalı olduğu acil durumlar ile hastanın bir organının kaybına veya fonksiyonunu ifa edemez hale gelmesine yol açacak durumun varlığı halinde, hastaya tıbbi müdahalede bulunmak rızaya bağlı olmayıp ilgili bireyin sağlığı için tıbbî bakımdan gerekli olan herhangi bir müdahale derhal yapılabilir
(Hasta Hakları Yönetmeliği madde 24; Avrupa Biyotıp Sözleşmesi madde 8). ${ }^{[6,16,17]}$ Bu durumlarda hastaya gerekli tıbbi müdahale yapılarak durum kayıt altına alınacak; mümkünse hastanın orada bulunan yakını veya kanuni temsilcisi; mümkün olmadığı takdirde de tıbbi müdahale sonrasında hastanın yakını veya kanuni temsilcisi bilgilendirilecektir.

Gerek yukarıda anılan durumlar, gerekse örneğini Avrupa Biyotıp Sözleşmesi 9. maddesinde "Önceden açıklanmış istek" iç başlığı altında yer alan "Müdahale sırasında isteğini açıklayabilecek bir durumda bulunmayan bir hastanın, tıbbî müdahale ile ilgili olarak önceden açıklamış olduğu istekler göz önüne alınacaktır." düzenlemesinde de söz konusu olan durumlar hukukumuzda yer alan "varsayılan rıza" kavramı ile açıklanmaktadır. ${ }^{[16]}$ Tıbbi müdahalede bulunulma zorunluluğunda olan hastaya, kendisinde olmaması gibi nedenlerle önceden rıza alınamıyorsa dahi, hastanın sağlığı daha ön planda olduğu için müdahalede bulunulacaktır. Hekim, hastayı önceden tanımadığı için somut olarak hastasına göre değil, soyut olarak bilgi ve tecrübelerine dayanacaktır. Yani, hekimin rızayı varsayarken alacağı ölçüt, rızası alınamayan hasta değil; makul ve ortalama bir hasta olacaktır. ${ }^{[18]}$ Varsayılan rıza bir hukuka uygunluk sebebi olup; hasta bakımından rızanın alınamaması durumunda varsayılan rızanın varlığından söz edilebiliyorsa, hekim hukuka uygunluk sebebi içinde hareket ediyor demektir. ${ }^{[9]}$

Rıza konusunda bir olasılık da "kanuni temsilcinin herhangi bir nedenle zorunlu olan tıbbi müdahaleye rıza göstermemesi" olarak karşımıza çıkabilmektedir. Kanuni temsilcinin hakkın kötüye kullanımı biçimindeki bu davranışı karşısında yapılabilecek olan ise Hasta Hakları Yönetmeliği madde 24/4'de düzenlenmiştir. ${ }^{[6]}$ Düzenlemeye göre kanuni temsilci tarafından rıza verilmeyen hallerde, müdahalede bulunmak tıbben gerekli ise, velayet ve vesayet altındaki hastaya tıbbi müdahalede bulunulabilmesi; Türk Medeni Kanununun 346 ve 487. maddeleri uyarınca mahkeme kararına bağlıdır. ${ }^{[19]}$

ifade edilen bu durumun, yani mahkeme kararına müracaat halinin az yukarıda açıklanan acil durumlar için geçerli bulunmadığı açıktır. Hekimlik Meslek Etiği Kuralları 26. maddesi de "Acil durumlar ile, hastanın reşit olmaması veya bilincinin kapalı olduğu ya da karar veremeyeceği durumlarda yasal temsilcisinin izni alınır. Hekim temsilcinin izin vermemesinin kötü niyete dayandığını düşünüyor ve bu durum hastanın yaşamını tehdit ediyorsa, durum adli mercilere bildirilerek izin alınmalıdır. Bunun mümkün olmaması durumunda, hekim başka bir meslektaşına danışmaya çalışır ya da yalnızca yaşamı kurtarmaya yönelik girişimlerde bulunur. Acil durumlarda müdahale etmek hekimin takdirindedir." düzenlemesi ile konuya açıklık getirmektedir.[20] 
Temel kural, 'tıbbi müdahalenin, hasta tarafından verilen rızanın sınırları içerisinde gerçekleştirilmesi” olmakla birlikte hastaya tıbbi müdahalede bulunulurken yapılan işlemin genişletilmesi gereği doğduğunda müdahale genişletilmediği takdirde hastanın bir organının kaybına veya fonksiyonunu ifa edemez hale gelmesine yol açabilecek tıbbi zaruret hâlinde rıza aranmaksızın tıbbi müdahale genişletilebilir (Hasta Hakları Yönetmeliği madde 31/son). ${ }^{[6]}$ Yukarıda anılan uluslararası ve ulusal mevzuat düzenlemeleri kapsamında, tıbbi müdahalenin hukuka uygun olduğundan söz edebilmenin temel koşullarından birini oluşturan hasta rızasının gereklilik ve şartları hüküm altına alındığı gibi; rızanın aydınlatmaya dayalı olmasının gerekliliği ve bu aydınlatmanın kapsamı da belirlenmiş bulunmaktadır.

Hasta Hakları Yönetmeliği "Bilgilendirmenin Kapsamı" başılıkı 15. maddesinde de belirtildiğine göre hastaya, hastalığın muhtemel sebepleri ve nasıl seyredeceği; tıbbi müdahalenin kim tarafından nerede, ne şekilde ve nasıl yapılacağı ile tahmini süresi; diğer tanı ve tedavi seçenekleri ve bu seçeneklerin getireceği fayda ve riskler ile hastanın sağlığı üzerindeki muhtemel etkileri; muhtemel komplikasyonları; reddetme durumunda ortaya çıkabilecek muhtemel fayda ve riskleri; kullanılacak ilaçların önemli özellikleri; sağlığı için kritik olan yaşam tarzı önerileri; gerektiğinde aynı konuda tıbbî yardıma nasıl ulaşabileceği hususlarında bilgi verilmesi gerekmektedir. ${ }^{[6]}$

Anılan düzenlemelere koşut olarak Hekimlik Meslek Etiği Kuralları'nın “Aydınlatılmış Onam” başııkı 26. maddesinde de detaylı olarak belirtildiği üzere hasta hekimi tarafindan sağlık durumu ve konulan tanı, önerilen tedavi yönteminin türü, başarı şansı ve süresi, tedavi yönteminin onun için taşıdığı riskler, verilen ilaçların kullanılışı ve olası yan etkileri, hastanın önerilen tedaviyi kabul etmemesi durumunda hastalığın yaratacağı sonuçlar, olası tedavi seçenekleri ve riskleri konularında aydınlatılmalıdır. Düzenlemeye göre yapılacak aydınlatma hastanın kültürel, toplumsal ve ruhsal durumuna özen gösteren bir uygunlukta olmalı, hasta tarafından anlaşılabilecek biçimde verilmelidir. Sağlıkla ilgili her türlü girişim, kişinin özgür ve aydınlatılmış onamı ile yapılabilir ve alınan onam, baskı, tehdit, eksik aydınlatma ya da kandırma yoluyla alındıysa geçersiz bulunmaktadır. ${ }^{[20]}$

Uygulamaya dönük olarak incelendiğinde de Yargıtay kararlarında istikrar kazanmış şekilde Avrupa Biyotıp Sözleşmesine ve diğer mevzuata atıf yapılarak rızanın kapsamı belirlenmekte ve bunun yanında salt müdahaleye rıza gösterilmiş olmasının yeterli olmadığı rızanın aydınlatmaya dayalı olarak alınması gerektiğine vurgu yapılmaktadır. Örneğin Yargıtay 13. Hukuk Dairesi'nin 04.07.2018 tarih E. 2016/25663K. 2018/7615 sayılı kararında “..Salt ameliyata rıza göstermek yeterli değildir. Ayrıca, komplikasyonların da izah edilmesi gerekmektedir. Ancak bu rızanın da aydınlatılmış rıza olması gerekir. Nitekim Hekimlik Meslek Etiği Kurallarının Aydınlatılmış Onam başlıklı 26. maddesinde düzenleme yapılmış ve "Hekim hastasını, hastanın sağık durumu ve konulan tanı, önerilen tedavi yönteminin türü, başarı şansı ve süresi, tedavi yönteminin hastanın sağglı̆ı için taşıdığı riskler, verilen ilaçların kullanılışı ve olası yan etkileri, hastanın önerilen tedaviyi kabul etmemesi durumunda hastalığın yaratacağı sonuçlar, olası tedavi seçenekleri ve riskleri konularında aydınlatır. Yapılacak aydınlatma hastanın kültürel, toplumsal ve ruhsal durumuna özen gösteren bir uygunlukta olmalıdır. Bilgiler hasta tarafindan anlaşılabilecek biçimde verilmelidir. Hastanın dışında bilgilendirilecek kişileri, hasta kendisi belirler. Sağlıkla ilgili her türlü girişim, kişinin özgür ve aydınlatılmıs onamı ile yapılabilir. Alınan onam, baskı, tehdit, eksik aydınlatma ya da kandırma yoluyla alındıysa geçersizdir. Acil durumlar ile, hastanın reşit olmaması veya bilincinin kapalı olduğu ya da karar veremeyeceği durumlarda yasal temsilcisinin izni alınır." düzenlemesiyle aydınlatmanın ne şekilde yapılacağı açıklanmıştır. Aydınlatılmış onamda ispat külfeti hekim ya da hastanededir." denerek somut olay bazında "davalılar, davacıya yapılan ameliyat sonucunda oluşabilecek olası komplikasyonların anlatıldığına ve davacının bu işleme rıza gösterdiğine dair aydınlatılmış onam alındığına dair bir delil sunmamışlardır. Muvafakatname başlığı altında dosyaya sunulan belge, gerekli aydınlatmayı içermediği gibi, yalnızca rıza mahiyetindedir. Aydınlatılmış onamda ispat külfeti hekim ya da hastanededir. Mahkemenin de kabulü bu şekildedir. Ancak, aydınlatma yükümlülügünün yerine getirilmemiş oluşu, yapılan müdahaleyi hukuka aykırı hale getirdiğinden, davalıların manevi tazminat dışında maddi tazminattan da sorumlu olduklarının kabulü gerekir." şeklinde karar gerekçesi oluşturulmuş bulunmaktadır. ${ }^{[21]}$

Hastanın aydınlatılması gereğinin tümüyle ortadan kalktığı durumlar da söz konusu olabilmektedir. Hasta Hakları Yönetmeliği 19. maddesi "hastanın manevi yapısı üzerinde fena tesir yapmak suretiyle hastalığın artması ihtimalinin bulunması ve hastalı̆ıı seyrinin ve sonucunun vahim görülmesi hallerinde, teşhisin saklanması caizdir. Hastaya veya yakınlarına, hastanın sağlık durumu hakkında bilgi verilip verilmemesi, yukarıdaki fikrada belirtilen şartlar çerçevesinde tabibinin takdirine bağlıdır. Tedavisi olmayan bir teşhis, ancak bir tabip tarafindan ve tam bir ihtiyat içinde hastaya hissettirilebilir veya bildirilebilir. Hastanın aksi yönde bir talebinin bulunmaması veya açıklanacağı şahsın önceden belirlenmemesi halinde, böyle bir teşhis ailesine bildirilir" hükmüne yer vermekte olup; 20. madde düzenlemesi çerçevesinde de hasta serbest iradesi ile ve yazılı olarak sağlık durumu hakkında kendisinin, yakınlarının ya da hiç kimsenin bilgilendirilmemesini talep edebilir. ${ }^{[6]}$ Zaruret hali olarak nitelendirilebilecek girişimin 
çok acil gerçekleştirilmesinin gerekmesi halinde aydınlatmadan vazgeçilebileceği gibi; hastanın aydınlatılması gereğinin ortadan kalkabileceği diğer bir durum da, uygulanması düşünülen tıbbi müdahale ile ilgili zaten bilgi sahibi olmasıdır, mesele hasta o anabilim dalında görev yapan bir hekim olabilir ya da hasta daha önce aynı müdahaleye uğradığından başka bir hekim tarafından daha önce aydınlatılmış olabilir. ${ }^{[22]}$

Aydınlatmaya dayalı rızanın alınma zamanı ve şekli de hukuka uygunluk anlamında önem arz etmektedir. Hastanın, tıbbi müdahale ile ilgili yapılacak bilgilendirmeyi algılayabileceği koşullarda aydınlatılması ve özgür iradesi ile karar verebileceği yeterli zamanın tanınması gerekmektedir. Tıbbi müdahaleden yeterli bir zaman önce gerçekleşmesi gereken aydınlatılmış rızanın alınma zamanına ilişkin mevzuatta tam bir netlik bulunmasa da; rızanın acil durumlar dışında her hâlükârda tıbbi müdahalenin başlamasından önce ve mümkün olduğunca hastanın düşünüp karara varmasına olanak verecek bir zaman aralığına sahip olmalıdır.

Tababet ve Şuabatı Sanatlarının Tarzı İcrasına Dair Kanun'un 70. maddesi büyük ameliyatlar için rızanın yazılı olmasını zorunlu kılmıştır. ${ }^{[10]}$ Hasta Hakları Yönetmeliği 28. maddesi de mevzuatın öngördüğü istisnalar dışında (organ ve doku alınmasında yazılı rıza şartı gibi), rızanın herhangi bir şekle bağlı olmadığını belirlemiştir. ${ }^{[6]}$ Sözlü olarak rıza gösterilebileceği gibi, kimi tahlil ve tetkiklere katılmanın zımni olarak rıza anlamına gelebileceği hususları öğretide tartışılıyor ya da kabul görüyor olsa da; olası ihtilaflarda ispat kolaylığı yönünden rızanın yazılı olarak alınması daha doğru olacaktır. Zira, Yargıtay 13. Hukuk Dairesi T. 18.9.2018 E. 2016/26894 K. 2018/8072; Yargitay13. Hukuk Dairesi T. 5.4.2018 E. 2015/41712 K. 2018/4243; Yargıtay13. Hukuk Dairesi T. 15.9.2014 E. $2013 / 26330$ K. $2014 / 27050$ sayılı örnek Yargitay içtihatlarında da belirlendiği ve istikrar kazanmış olduğu üzere aydınlatılmış onamın alındığının ispat külfeti hekime ve ilgili hastaneye ait bulunmaktadır. ${ }^{[23-25]}$

Hasta Hakları Yönetmeliği'nin 2014 yılında değişik "Rıza Formu" başlıklı 26. maddesi de yazılı rıza halinde alınacak forma ilişkin düzenlemeleri yapmış bulunmaktadır. Anılan madde metnine göre "Mevzuatta öngörülen durumlar ile uyuşmazlı̆ga mahal vermesi tıbben muhtemel görülen tıbbi müdahaleler için sağlık kurum ve kuruluşunca (bilgilendirmenin kapsamının düzenlendiği) 15 inci maddedeki bilgileri içeren rıza formu hazırlanır. Rıza formunda yer alan bilgiler; sözlü olarak hastaya aktarılarak rıza formu hastaya veya kanuni temsilcisine imzalatılır. Rıza formu iki nüsha olarak imza altına alınır ve bir nüshası hastanın dosyasına konulur, diğeri ise hastaya veya kanuni temsilcisine verilir. Acil durumlarda tıbbi müdahalenin hasta tarafindan kabul edilmemesi durumunda, bu beyan imzalı olarak alını, imzadan imtina etmesi halinde durum tutanak altına alınır. Rıza formu bilgilendirmeyi yapan ve tıbbi müdahaleyi gerçekleştirecek sağlık meslek mensubu tarafindan imzalanır. Verilen bilgilerin doğruluğundan ilgili sağık meslek mensubu sorumludur. Rıza formları arşiv mevzuatına uygun olarak muhafaza edilir."'[6]

Tüm bu açıklamalar kapsamında tıbbi müdahalenin hukuka uygunluk şartlarından birisi olan rızanın geçerli olabilmesi için özetle; bir endikasyonun varlığı / rızanın ehliyetli hasta -küçük veya kısıtlı ise kanuni temsilcisi (veli/vasi)- tarafından verilmiş olması / rızanın müdahalede bulunmaya yetkili kişiye yönelmiş olması / iradeyi sakatlayan her hangi bir nedenin bulunmaması (hastanın rızasını gösterirken, herhangi bir hataya düşmemiş olması, aldatılmamış olması ve tehdit edilmemiş olması) / rızanın hekimin yaptığı aydınlatmaya dayanması / aydınlatmanın, gerekli kıldığı tüm bilgilendirme koşulları taşıması/ ahlaka, adaba ve hukuka aykırı olarak alınmaması gerekleri söylenebilecektir.

3. Tıbbi müdahalenin dikkat ve özen yükümlülügüne uygun bir biçimde, tıp biliminin en son veri ve olanaklarına uyumlu olarak yerine getirilmesi

Tıbbi müdahalenin yetkili kişi tarafından ve hastanın aydınlatılmış rızası ile yapılması hukuka uygunluk şartı olmakla birlikte yeterli bulunmamaktadır. Hekim tıbbi uygulamalarda bulunurken tıp mesleğinin gerektirdiği şartları yerine getirmeli, tıp bilimi ve deontoloji kurallarını gözetip uygulamak zorundadır. Aksi halde eylem ve davranışları hukuka aykırılık nedeniyle sorumluluğunu gerektirecektir.

Avrupa Biyotıp Sözleşmesi'nin 4. maddesinde "Meslek Kurallarına Uyma” başığı altında; "Araştırma dahil, sağılı alanında herhangi bir müdahalenin, ilgili mesleki yükümlülükler ve standartlara uygun olarak yapılması gerekir." denilmektedir. Anılan 4. madde kapsamı karşısında, her türlü tıbbi müdahalenin mesleki yükümlülükler ve standartlara uygun olması gerektiği benimsenmiştir. ${ }^{[16]}$

Hasta Hakları Yönetmeliğinin 11. maddesinde de hastanın, modern tıbbi bilgi ve teknolojinin gereklerine uygun olarak teşhisinin konulmasını, tedavisinin yapılmasını ve bakımını istemek hakkına sahip olduğu; tababetin ilkelerine ve tababet ile ilgili mevzuat hükümlerine aykırı veya aldatıcı mahiyette teşhis ve tedavi yapılamayacağı hüküm altına alınmış bulunmaktadır. Yönetmeliğin "Tıbbi Özen Gösterilmesi" başlıklı 14. maddesinde "Personel, hastanın durumunun gerektirdiği tıbbi özeni gösterir. Hastanın hayatını kurtarmak veya sağı̆ı̆ını korumak mümkün olmadığı takdirde dahi, ıstırabını azaltmaya veya dindirmeye çalışmak zorunludur." 
şeklindeki ifade ile genel bir tanımlama da yapılmış bulunmaktadır. ${ }^{[6]}$

Tıbbi Deontoloji Tüzüğü 11 ve 13. maddeleri düzenlemeleri ile de tecrübe maksadı ile insanlar üzerinde hiç bir cerrahi müdahale yapılamayacağı gibi aynı maksatla kimyevî, fizikî veya biyolojik şekilde herhangi bir tedavi de tatbik edilemeyeceği; hekimin ilmî icaplara uygun olarak teşhis koyarak, gereken tedaviyi uygulayacağı belirtilmiş bulunmaktadır. 11. maddede ayrık bir durum olarak "evvelce tecrübe edilmiş olmamakla beraber, zarar vermesine ihtimal bulunmayan ve hastayı kurtarması kati görülen bir müdahale yapılabilir" ibaresine de yer verilmiştir. ${ }^{[2]}$

Yargıtay 4. Hukuk Dairesi'nin 7.3.1977 tarih $1976 / 6297$ E. 1977/2541 K. sayılı kararında da "Hekim, tababeti yerine getirirken, tıbbı uygularken kişinin yaşamasını düzenlemek, sağlığını sağlayabilmek amacıyla çeşitli faaliyetlerde bulunmaktadır. Bu faaliyetler hastalığın teşhisi, gerekli ilaçların verilmesi, cerrahi müdahalelerin yapılması, hastalığın devamlı olarak gözetilmesi, gerektiğinde yan etkili tedavi yollarına, yeni usullere başvurulması gibi çeşitli konuları kapsamaktadır. İşte hekim bu faaliyetlerde bulunurken bazı mesleki şartları yerine getirmek hastanın durumuna değer vermek ve geniş bir deyimle tıp biliminin kurallarını gözetip uygulamak zorundadır. Aksi halde hekim tıp biliminin verilerini yanlış ya da eksik uygulamışsa, mesleğine gerektirdiği özel görevlere gereği ve yeteri kadar uymamışsa mesleki kusuru var demektir ki, bu eylem ve davranışı da hukuka aykırılık nedeniyle sorumluluğunu gerektirecektir.

Hekim ile hasta arasında sözleşme ilişkisi bulunması ve tıbbi müdahaleye hastanın rıza göstermesi ya da ıstırar hali asla durumu etkilemeyecektir. Çünkü, rızanın ya da ıstırar halin (zorunluluk) varlığı halinde hekimin davranışının bütün sonuçlarının meşru sayılması, hukuka uygun addedilmesi düşünülemez. Davranışın ve illiyet bağının meşruluğu ancak kullanılan araç ve uygulanan metodun gerektirdiği bütün tedbirlerin alınmasında söz konusu olabilir. Tababette de aynı kural geçerlidir. Sorumsuzluktan yararlanabilmek için tıp sanatının kurallarına, gereken tedbirlere uymak ve bu sınırlar içinde hareket etmek gereklidir. Diğer bir deyimle şayet tip ilmi hekimin yaptığı müdahalelere cevaz veriyorsa, bunu yapan hekim, tıp mesleğince tecviz edilen bir faaliyette bulunmuş demektir ki, hakkın icrası nedeniyle, eylemi hukuka aykırı sayılamaz. Keza hekim, hastanın daha az önemdeki bir hukuki menfaatini tehlikeye ya da zarara sokarken, daha büyük değerdeki bir hukuki yararı ancak bu şekilde kurtarabiliyorsa hukuka aykırı davranışta bulunmamış olacaktır. Söz gelimi; anneyi kurtarmak amacıyla çocuğun düşürülmesi, sıhhatin korunması ve düzeltilmesine yönelmiş tedavi ve müdahaleler böylece hukuka uygun hale gelmektedir. (Dr. Köksal Bayraktar - Hekimin tedavi nedeniyle cezai sorumluluğu - İstanbul 1972 Sayfa 71). Toplum yararının kişi yararına ağır bastığı durumlarda da kural aynıdır. Türk Doktrininde de üstün yarar görüşü olarak nitelenen bu görüşe rağmen, gerçekten zorunlu müdahale halleri dışında mağdurun rızasına önem verilmesi ile artık rıza teorisine dönüldüğü müşahede edildiğinden rıza konusu üzerinde kısaca durulmasında yarar görülmüştür. (Bayraktar - a.g.e. - 73, 78 vd.) (Sulhi Dönmezer/Sahir Erman - Nazari ve Tatbiki Ceza Hukuku - Cilt (II - 56) (Çetin Özek - Hekim ve Hukuk, Tıbbi Müdahalede Bulunmak Hakkının Sınırları - Istanbul Tıp Fakültesi Mecmuası 1965 - Cilt XXVIII, Sayfa - 4, Sayfa 449). Çünkü olayımızda da tıbbi müdahale, açık olmamakla beraber zımni ya da mefruz rızaya dayanmaktadır.

Bayraktar'ın da belirttiği gibi, (a.g.e. - 83) kişinin hiçbir hakkı sınırsız değildir. Sağlık ve yaşama haklarının da bir sınırı bulunmaktadır, kişi ancak tedavi olmak, bir hastalığı önlemek için rızasını verebilir. Kişiler kendi vücutları üzerinde ayrık durumlar hariç ancak kendileri tasarrufta bunabilir ve tehlikelere karşı yine kendisi karar verebilir. Tıbbi müdahalelerde de bu genel kuruldan ayrilmamak gerekir. Tıbbi müdahaleler ve hekimin girişeceği diğer eylemler kişinin sağ/ı̆̆ını, vücut bütünlüğünü ilgilendirdiği, muhtemel tehlikeleri meydana getirici nitelikte olduğu için, bunların gerçekleştirilmesine karar verme yetkisi hekime değil, müdahalelere maruz kalacak kişiye (hastaya) aittir. Yalnız bu rızanın hukuken geçerli olabilmesi için kişinin, sağlık durumunu, yapılacak müdahaleyi ve etkileri ile sonuçlarını bilmesi, (Bayraktar - a.g.e. - 125 vd.) bu konuda yeteri kadar aydınlanması ve iradesini bildirirken baskı altında kalmaması, serbest olması gerekir. Bu itibarladır ki ancak aydınlanmıs ve serbest bir irade sonucu verilmiş rıza hukuken değeri olan bir rızadır. (Bayraktar - a.g.e. - 79-80 ve orada anilan eserler) Hatta C. Musotto; daha ileri gitmekte ve "kişi, sosyal fonksiyonlarını önemli ölçüde aksatacak müdahalelere razı olmak yetkisine sahip değildir" demek suretiyle 3. bir şart öngörmektedir. (Bayraktar - a.g.e. - 80, dip not 64 ; 104) Rızanın geçerli sayılabilmesi için ayrıca, tıp mesleğinin bu çeşit müdahalelere cevaz vermesi yani bu konuda bir müdahaleye hekimin hakkı olması gereklidir. (Çetin Özek - a.g.m. - 455). Nitekim Umumi Hıfzısıhha Kanununun 70. maddesinde de rızanın aranacağı ilke olarak belirtilmiştir. O halde yukarıdaki açıklamalardan çıkan sonuca göre; hastanın rızası ve hekimin tıbbi müdahalede bulunma hak ve görevine sahip oluşu, sonucu ne olursa olsun tıbbi müdahalenin hukuka uygun olduğunun kabulünü gerektirmez. Türk hukukunda da kabul edilen ve yukarıda kısaca değinilen karma görüşe göre; Hekim sağlıkla ilgili fiillerde, rızayı sağladıktan sonra tıp biliminin sınırları içinde hareket etmek yükümlülügü altındadır ve hastanın rızasının kapsamına bağlı bulunmamaktadır" denilmektedir. ${ }^{[26]}$

Anılan Yargıtay kararından da açıkça anlaşılabileceği gibi; sadece hastanın rızasının varlığı ve hekimin tıbbi müdahalede bulunma hak ve görevine sahip oluşu müdahalenin hukuka uygunluğunu sağlamaya yetmemekte; aynı zamanda, hekimin teşhis ve tedavi yöntemlerini belirlerken ve uygularken tıp biliminin esasları ve ilkeleri çerçevesinde hareket etmesi de beklenmektedir. 
Nitekim Yargitay 13. Hukuk Dairesi 18.9.2018 tarih 2016/26894 E 2018/8072 K sayılı kararında "Vekil, hastanın zarar görmemesi için, mesleki tüm şartları yerine getirmek, hastanın durumunu tıbbi açıdan zamanında ve gecikmeksizin saptayıp, somut durumunun gerektirdiği önlemleri eksiksiz bir şekilde almak, uygun tedaviyi de yine gecikmeden belirleyip uygulamak zorundadır. Asgari düzeyde dahi olsa bir tereddüt doğuran durumlarda, bu tereddütü ortadan kaldıracak araştırmaları yapmak ve bu arada da koruyucu tedbirleri almakla yükümlüdür. Çeşitli tedavi yöntemleri arasında bir seçim yapılırken, hastanın ve hastalığın özellikleri göz önünde tutulmak, onu risk altına sokacak tutum ve davranışlardan kaçınmak ve en emin yol seçilmek gerekir. Gerçekten de müvekkil (hasta) mesleki bir iş gören vekilden, tedavinin bütün aşamalarında titiz bir ihtimam ve dikkat beklemek hakkına sahiptir. Gereken özen görevini göstermeyen vekil, BK 394/1 maddesi hükmü uyarınca, vekaleti gereği gibi ifa etmemiş sayılmalıdır." gerekçesine yer vermiş bulunmaktadır. ${ }^{[27]}$

Bu çerçevede hukuka uygunluk koşullarına bağı olarak hareket eden hekim, aynı zamanda tıbbın gerek ve kurallarına da uygun davranmışsa, buna rağmen doğacak olumsuz sonuçlardan sorumlu tutulmayacaktır. ${ }^{[28]}$

\section{Kısaltmalar}

a.g.e., adı geçen eser.

a.g.m., adı geçen makale.

\section{KAYNAKLAR}

1. Türkiye Cumhuriyeti Anayasası; Kanun Numarası : 2709 Kabul Tarihi : 18/10/1982 Yayımlandığı Resmî Gazete : Tarih : 9/11/1982 Sayı : 17863 (Mükerrer) Yayımlandığı Düstur: Tertip: 5 Cilt :22 Sayfa : 3 Erişim Tarihi: 16.10.2019 https://www.mevzuat.gov.tr/ MevzuatMetin/1.5.2709.pdf

2. Tıbbi Deontoloji Nizamnamesi; Bakanlar Kurulu Kararının Tarihi : 13.1.1960, No: 4/12578 Dayandığı Kanunun Tarihi: 23.1.1953, No: 6023 Yayımlandığı R. Gazetenin Tarihi : 19.2.1960, No: 10436 Yayımlandığı Düsturun Tertibi : 3, Cildi: 41,S.164 Erişim Tarihi: 16.10.2019 https://www.mevzuat.gov.tr/ MevzuatMetin/2.3.412578.pdf

3. Anayasa Mahkemesi Bireysel Başvuru Numarası : 2013/1789Karar Tarihi : 11/11/2015 Resmi Gazete Tarihi: 24 Aralık 2015 Resmi Gazete Sayısı: 29572 11.11.2015 tarih ve 2013/1789 sayılı kararı. Erişim Tarihi : 16.10.2019 http://muw.kazanci.com/kho2/ibb/ files/amkb2013-1789.htm

4. Demir S. Kamu Görevlisi Hekimlerin Tıbbi Müdahaleden Kaynaklanan Sorumluluğu Ankara: Seçkin Yayınclık; 2018, s.35.

5. Biyotıp Araştırmalarına Illişkin İnsan Hakları ve Biyotıp Sözleşmesine Ek Protokol; Bakanlar Kurulu Karar Tarihi: 05.05.2011 Karar Numarası: 2011/1827 Yayımlandığı Resmi Gazete Tarihi: 11.06.2011 Resmi Gazete Sayısı: 27961 (Mükerrer) Erişim Tarihi:16.10.2019 https:// unw.resmigazete.gov.tr/eskiler/2011/06/20110611M1-4.htm

6. Hasta Hakları Yönetmeliği; Resmî Gazete Tarihi: 01.08.1998 Resmî Gazete Sayısı: 23420 Erişim Tarihi : 16.10.2019 https://www. mevzuat.gov.tr/Metin.Aspx?MevzuatKod=7.5.4847\&Mevzuatlliski= 0\&sourceXmlSearch=hasta\%20haklar\%C4\%B1

7. Hatırnaz Erol G. Özel Hastanelerin Hukuki Sorumluluğu ve Hasta Hakları, 5.Baskı. Ankara: Seçkin Yayıncılık; 2017. s.132.

8. Çakmut YÖ. Aydınlanma ve Rıza. Roche Sağıı Hukuku Günleri, Tebliğ. s.4.

9. Hakeri H. Tıp Hukuku, 1. Baskı. Ankara: Seçkin Yayıncılık; 2007. ss.33-166.
10. Tababet ve Şuabatı San'atlarının Tarzı İcrasına Dair Kanun; Kanun Numarası : 1219 Kabul Tarihi : 11/4/1928 Yayımlandığı Resmî Gazete : Tarih : 14/4/1928 Sayı : 863 Yayımlandığı Düstur : Tertip : 3 Cilt : 9 Sayfa : 126. Erişim Tarihi: 16.10.2019 https://www.mevzuat. gov.tr/MevzuatMetin/1.3.1219.pdf

11. Tıpta ve Diş Hekimliğinde Uzmanlık Eğitimi Yönetmeliği; Resmî Gazete Tarihi: 26.04.2014 Resmî Gazete Sayısı: 28983. Erişim Tarihi: 16.10.2019 https://www.mevzuat.gov. tr/Metin. Aspx? MevzuatKod=7.5.19629\&Mevzuatlliski=0\& sourceXmISearch=T\%C4\%B1 pta\%20ve\%20Di\%C5\%9F\%20 Hekimli\%C4\%9Finde\%20Uzmanl\%C4\%B1 k\%20E\%C4\%9Fitimi\%20 Y\%C3\%B6netmeli\%C4\%9Fi

12. Dünya Tabipler Birliği Lizbon Hasta Hakları Bildirgesi -1981 ; Erişim Tarihi: 16.10.2019. https://sbu.saglik.gov.tr/hastahaklari/lizbon.htm

13. Avrupa Hasta Haklarının Geliştirilmesi Bildirgesi Olarak 28-30 Mart 1994 Amsterdam Bildirgesi; Erişim Tarihi: 16.10.2019. https://sbu. saglik.gov.tr/hastahaklari/amsterdam.htm

14. Dünya Tabipler Birliği Bali Bildirgesi - 1995 ; Erişim Tarihi: 16.10.2019. https://sbu.saglik.gov.tr/hastahaklari/bali.htm

15. Hasta Haklarına İlişkin Avrupa Statüsü (Ana Sözleşmesi) Temel Doküman - Kasım 2012; Erişim Tarihi: 16.10.2019. https://sbu. saglik.gov.tr/hastahaklari/avrupastatusu.htm

16. Biyoloji Ve Tıbbın Uygulanması Bakımından İnsan Hakları Ve Insan Haysiyetinin Korunması Sözleşmesi: İnsan Hakları Ve Biyotıp Sözleşmesinin Onaylanmasının Uygun Bulunduğuna Dair Kanun; Kanun No:5013 Kabul tarihi: 03.12.2003. Erişim Tarihi: 16.10.2019. https://www.tbmm.gov.tr/kanunlar/k5013.html

17. Umumi Hıfzıssıhha Kanunu; Kanun Numarası : 1593 Kabul Tarihi : 24/4/1930 Yayımlandığı Resmi Gazete : 6/5/1930 Sayı : 1489 Yayımlandığı Düstur : Tertip : 3 Cilt : 11 Sayfa : 143. Erişim Tarihi: 16.10.2019. https://www.mevzuat.gov.tr/MevzuatMetin/1.3.1593.pdf

18. Oral T. Ankara Barosu Dergisi 2011;2:203.

19. Türk Medeni Kanunu ;Kanun Numarası : 4721 Kabul Tarihi : 22/11/2001 Yayımlandığı Resmî Gazete : Tarihi : 8/12/2001 Sayı : 24607 Yayımlandığı Düstur : Tertip : 5 Cilt : 41. Erişim Tarihi: 16.10.2019. https://www.mevzuat.gov.tr/MevzuatMetin/1.5.4721.pdf

20. Hekimlik Meslek Etiği Kuralları; Yayın Tarihi : 01.02.1999. Son Güncelleme: 26 Ağustos 2015. Erişim Tarihi: 16.10.2019. https:// www.ttb.org.tr/mevzuat/index.php?option=com_content\&task=vie w\&id $=65 \&$ ltemid $=31$

21. Yargitay 13. Hukuk Dairesi'nin 04.07.2018 tarih E. 2016/25663K. 2018/7615 sayılı kararı. Erişim Tarihi: 16.10.2019. http://www. kazanci.com/kho2/ibb/files/dsp.php?fn=13hd-2016-25663.htm\& $k w=+E .+` 2016 / 25663+K . `+` 2018 / 7615 `+\# f m$

22. Polat O. Tıbbi Uygulama Hataları. Ankara: Seçkin Yayıncılık;2005, s.95

23. Yargıtay 13. Hukuk Dairesi'nin 18.9.2018 tarih E. 2016/26894 K. 2018/8072 sayılı kararı. Erişim Tarihi: 16.10.2019. http://www. kazanci.com/kho2/ibb/files/dsp.php?fn=13hd-2016-26894.htm\& $k w=E .+` 2016 / 26894 `+K .+` 2018 / 8072 ` \# f m$

24. Yargıtay13. Hukuk Dairesi'nin 5.4.2018 tarih E. 2015/41712 K. 2018/4243 sayılı kararı. Erişim Tarihi: 16.10.2019. http://www. kazanci.com/kho2/ibb/files/dsp.php?fn=13hd-2016-26894.htm\& $k w=E .+2016 / 268944^{\prime}+K .+` 2018 / 8072 ` \# f m$

25. Yargıtay13. Hukuk Dairesi'nin 15.9.2014 tarih E. 2013/26330 K. 2014/27050 sayılı kararı. Erişim Tarihi: 16.10.2019. http://www. kazanci.com/kho2/ibb/files/dsp.php?fn=13hd-2013-26330.htm\& $\mathrm{kw}={ }^{\prime} 2013 / 26330 `+K .+2014 / 27050 `++\# \mathrm{fm}$

26. Yargitay 4. Hukuk Dairesi'nin 7.3.1977 tarih 1976/6297 E. 1977/2541 K. sayılı kararı. Erişim Tarihi: 16.10.2019. http:// www.kazanci.com/kho2/ibb/files/dsp.php?fn=4hd-1976-6297. $h \mathrm{tm} \& \mathrm{kw}=` 1976 / 6297^{`}+\# \mathrm{fm}$

27. Yargitay 13. Hukuk Dairesi'nin 18.9.2018 tarih 2016/26894 E 2018/8072 K sayılı kararı. Erişim Tarihi: 16.10.2019 http://www. kazanci.com/kho2/ibb/files/dsp.php?fn=13hd-2016-26894. htm\&kw=`2016/26894`+\#fm

28. Yargıtay 13. Hukuk Dairesi'nin 5.4.2018 tarih 2015/41712 E. 2018/4243 K. sayılı kararı. Erişim Tarihi: 16.10.2019 http://www. kazanci.com/kho2/ibb/files/dsp.php?fn=13hd-2015-41712. $h t m \& k w=` 2015 / 41712^{`}+E \# f m$ 